\title{
Biotechnological applications of recombinant single-domain antibody fragments
}

\author{
Ario de Marco
}

\begin{abstract}
Background: Single-domain antibody fragments possess structural features, such as a small dimension, an elevated stability, and the singularity of recognizing epitopes non-accessible for conventional antibodies that make them interesting for several research and biotechnological applications.

Results: The discovery of the single-domain antibody's potentials has stimulated their use in an increasing variety of fields. The rapid accumulation of articles describing new applications and further developments of established approaches has made it, therefore, necessary to update the previous reviews with a new and more complete summary of the topic.

Conclusions: Beside the necessary task of updating, this work analyses in detail some applicative aspects of the single-domain antibodies that have been overseen in the past, such as their efficacy in affinity chromatography, as co-crystallization chaperones, protein aggregation controllers, enzyme activity tuners, and the specificities of the unconventional single-domain fragments.
\end{abstract}

\section{Introduction}

Conventional poly-and monoclonal antibodies are still indispensable reagents in basic research and diagnostics. Nevertheless, both of them have some shortcomingsmost of all the batch-to-batch variability of the polyclonal antibodies and the elevated costs and long time necessary for the production of the monoclonal ones. Furthermore, their dimension is detrimental for some diagnostic and therapeutic applications since it limits the efficient penetration into solid tumors and the passage through the blood-brain barrier. All these reasons urged the development of strategies aimed at the production of alternative scaffolds [1] and recombinant antibodies of smaller dimensions that could be easily selected, produced, and manipulated using standard molecular biology techniques.

Although a vast number of recombinant antibody structures has been proposed [2], the single chain (scFv) and the single domain ( $\mathrm{VHH}, \mathrm{VH}$, and NAR V) formats are the most widespread for both research and industrial applications [2-4]. Recombinant antibodies seem particularly promising as immunoconjugates $[5,6]$

Correspondence: ario.demarco@ung.si

University of Nova Gorica (UNG), Vipavska 13, PO Box 301-SI-5000, Rožna Dolina (Nova Gorica), Slovenia and for activating the biosensor chip surfaces for detecting specific antigens [7]. Specifically, VHHs succeed in targeting brain epitopes by transmigrating through the blood-brain barrier [8,9], can be used for tuning and detecting the activity of cell proteins in vivo [10-13], provide better diffusion in fixed cells in comparison to conventional antibodies [14], and can simplify the generation of anti-idiotypic antibodies suitable for vaccination [15].

The success of the technology makes it impossible to review the entire literature concerning the different classes of antibody fragments and their applications in biology. The modes of application of VHHs, even though recently reviewed $[4,16]$, constantly increase in numbers with the publication of new reports describing innovative uses. Therefore, this paper will on the one side integrate information concerning the established biotechnological utility of single-domain antibodies with the most recent data. On the other side, it will overview the potentials of the different classes of single-domain antibodies that developed massively in the last two years, such as immunoaffinity, assisted crystallography, protein aggregation and activity tuning, and toxin inactivation, for which a systematic update is now necessary. 


\section{Unconventional single-domain antibodies}

Camelidae single-chain antibodies and their recombinant $\mathrm{VHH}$ domains have ceased to be an exotic group with a merely theoretical interest and have become an established tool in biology and biotechnology. The number of publications that increases year in and year out testifies that an ever larger number of research groups work successfully with these molecules in different fields. Although not equally widespread, also the single chain antibodies of shark origin (IgNAR) have seen an increasing interest as a source of single-domain antibodies. In contrast, the scientific community is probably less aware of the qualities of other single-domain antibodies, the existence of which was for long time considered a simple anomaly (Figure 1).

$\mathrm{VHH}$ stability has been attributed to the mutation of the hydrophobic residues responsible for the interaction between VL and VH domains [17]. However, there are single-domains, such as the human $\mathrm{VH}$ domain HEL4, that conserve conventional $\mathrm{VH}$ hallmarks but are stable even in the absence of the pairing VL partner. HEL4 crystal structure suggests that the reason of its stability is due to an interaction by which the CDR 1 partially masks the hydrophobic residues otherwise exposed on the framework region [18]. This structural arrangement resembles the stabilizing role of CDR3 residues observed in some VHHs, resulting in a loop partially bending over the framework [19] and indicates that singledomain antibodies can display different conformational patterns to prevent the exposure of potentially destabilizing amino acids. Although useful, the necessity to renounce the loop flexibility that contributes to the

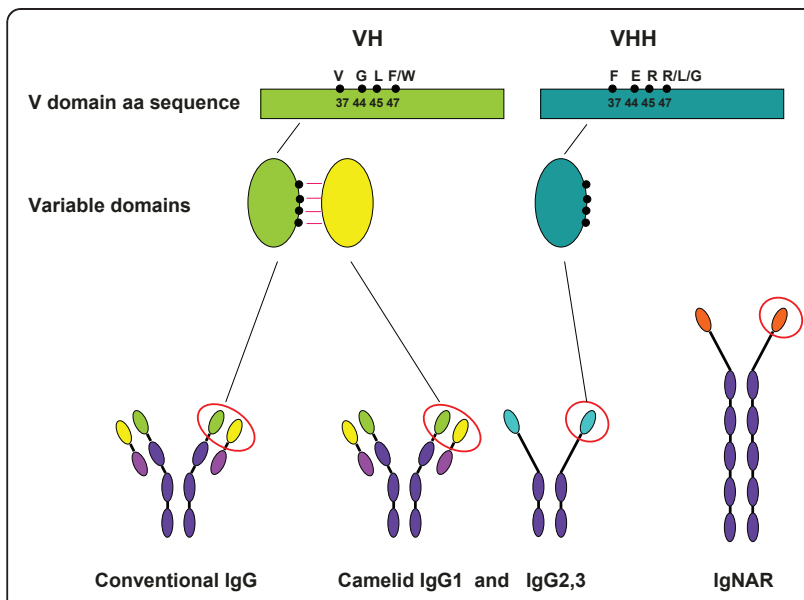

Figure 1 Representation of the single-domain antibody specific features. Single-domain antibodies can derive from different immunoglobulines. Camelid VHs and VHHs differ for four hallmark amino acid residues that are crucial for preserving the $V$ domain stability when it is expressed paired to the VL domain or alone, respectively. framework stability constrains the theoretical variability of the paratope in terms of shape and residues. In this sense, a VH domain stabilized by the sole replacement of the hydrophobic residues involved in the VL interaction has been proposed since it would preserve the maximal structural adaptability of the CDR3 and offer an ideal scaffold for generating libraries with loops hypermutated with respect to both length and residue combination $[17,20,21]$. At the same time, these libraries derived from human VHs would represent a source for selecting binders with no immunogenic response and, therefore, of great therapeutic interest.

For this purpose, it is relevant that individual VHs not only have structural features similar to those of the VHHs in terms of thermal stability and refolding efficiency [22-24], but also that they are perfectly functional in terms of antigen-binding characteristics, as initially reported by Ward et al. [25]. The mouse VH domains isolated by panning against lysozyme had affinity in the $20 \mathrm{nM}$ range for their antigen and the same binding affinity was calculated for other $\mathrm{VH}$ single-domain antibodies isolated successively from a semi-synthetic library [26]. Another single-domain antibody (clone V86) was successfully used in several immunotechniques [27] and its nature as a structurally independent domain was confirmed by the observation that its specificity and affinity for the antigen were almost completely lost when it was coupled with a VL domain for reconstituting a scFv.

Single-domains with $\mathrm{VH}$ signature were isolated also after panning of Camelidae libraries designed for sampling only VHHs and their presence was considered as the consequence of material contaminations during the amplification steps of the single-domain DNA [28,29]. However, these VHs were functional and stable, indicating that they possessed structural features of independent single-domain antibodies.

Finally, specific classes of VH domains have been identified recently both in llama and mouse for which the presence of the light chains is entirely optional since they can either form conventional or equally functional but single-domain antibodies [30,31]. The stability and functionality of independent $\mathrm{VHs}$ is maintained also when they are expressed as intrabodies [32,33].

The identification of stable $\mathrm{VH}$ domains has been recognized as a potential opportunity to widen the overall pool of functional single-domain antibodies. From this perspective, the protocol used for single-domain library preparation has been modified for obtaining mixed libraries containing the whole repertoire of both $\mathrm{VH}$ and $\mathrm{VHH}$ domains. Stable and antigen-specific $\mathrm{VH}$ domains were isolated by panning from these libraries [34,35].

In contrast to VHs, only few independent VL domains have been reported as maintaining the binding capacity 
and specificity of the complete antibody molecule. These result from the in vitro cleavage of functional IgG fragments, as in the case of the VL binder specific for the streptococcal protein L [36] and of the VL-barnase immunotoxin that accumulates soluble and functional in E. coli cytoplasm [37].

\section{Targeting bacteria and phages}

Antibodies directed against pathogenic bacterial-specific surface antigens enable to identify them in, and remove them from, biological samples. The advantage of using fragment antibodies lies in the fact that they lack the Fc domain, an IgG conserved region recognized by related proteins expressed by bacteria belonging to different species. Consequently, conventional antibodies are not suitable for specifically identifying a bacterial sub-group inside a complex population, whereas single-domain antibodies constitute a reliable tool for these diagnostic applications. For instance, single-domain isolated from a VH library [20] and directed towards the staphylococcal Protein A has been used in diagnostic applications based on both nanoparticles [38] and nanoaggregateembedded beads [39].

Antibodies can be used for preventing in vivo the attachment of pathogenic bacteria to the target cells by competing with them for the host cell receptors [40,41]. The main limitation of such a strategy is that it is difficult to provide constantly the necessary amount of antibody because of the titer dilution and molecule clearance. The environment colonization with microbial cell factories that ensure the production and secretion of the competitor antibodies in situ represents a possibility to overcome this drawback, but IgG are not suitable for this application, in the way that antibody fragments are. Recombinant antibodies in $\mathrm{scFv}$ format raised against the streptococcal cell surface antigenI/II and transformed into lactobacilli were therefore used to infect the oral cavity of model rats to inhibit Streptococcus mutans, the agent responsible for dental caries. The method succeeded in decreasing the development of dental caries [42] and resulted more effective when antibody production was induced by a constitutive promoter [41]. Nevertheless, VHHs were successively preferred to scFvs because of their superior structural robustness and demonstrated their effectiveness in controlling the damage [43]. Orally administrated, transformed lactobacilli were also successfully used for delivering anti-TNF nanobodies to the colon at a concentration sufficient to significantly reduce chronic colitis [44].

The small dimensions of VHHs allow also their fusion to relatively large tags without negative effects in terms of recombinant yields. Therefore, their fusion to glucose oxidase for inducing the production of active forms of oxygen with microbicidal effect in the oral cavity has been proposed. This approach may offer a synergistic effect due to the contribution of the direct competition plus the antimicrobial enzymatic activity, but its effectiveness remains uncertain in vivo $[43,45]$.

Mutagenesis is another tool that can be exploited to improve the in vivo reliability of antibacterial VHHs by selecting variants with superior features for a critical condition. A set of anti-E. coli F4 fimbriae antibodies was isolated and the most promising clone was further characterized. Even though very effective in vitro, it protected poorly the piglets from intestinal infection since it was rapidly degraded [40]. Therefore, its proteolytical stability was increased by mutagenesis for obtaining a significantly more effective binder suitable for oral treatment [46].

The control of the pathogenic bacterial infection can be also addressed by reducing the bacterial resistance to antibiotics. Microorganisms can survive in the presence of inhibitors since they produce enzymes that metabolize the antibiotics. This is the case of the beta-lactamase, a secreted enzyme that hydrolyzes ampicillin-like antibiotics. VHHs with beta-lactamase inhibitory effect have been isolated [47] demonstrating the feasibility of selecting single-domain antibodies that could silence this resistance strategy, although no biotechnological application has followed so far.

Unique features of the single-domain antibodies can be illustrated by a further example. The addition of recombinant $\mathrm{VHH}$ raised against a phage tail protein involved in the host recognition prevented the infection of Lactococcus lactis cultures by the p 2 bacteriophage $[48,49]$. Subsequently, the lactobacilli have been engineered to produce directly phage-neutralizing $\mathrm{VHHs}$ at a rate sufficient for protecting themselves from infections [50]. This method represents an interesting approach for vaccinating microorganisms of biotechnological interest with the scope of protecting them from harmful aggressions of biotic and abiotic origin.

\section{Single-domain antibodies against fungi and protozoans}

The potentials of single-domain antibodies have been only scarcely applied to fungi and protozoans. Nevertheless, those few projects have significantly contributed to the understanding of some general antibody structural features. It is the case of the antibodies raised against a cell wall protein of Malassezia furfur, a fungus implicated in dandruff. Since the selected VHH antibodies should be potentially included in a shampoo formulation, they had to resist to the harsh chemical conditions brought about by elevated concentrations of anionic and nonionic surfactants. Therefore, the panning washing conditions were adapted to represent the high-detergent content of shampoos [51]. This approach enabled the recovery of $\mathrm{VHHs}$ with specifically increased stability 
under denaturing conditions and to identify the key role of arginine at position 44 for improving this characteristic.

IgNARs, the single-chain antibodies of shark origin, have been used for identifying variable domains of the malarial Apical Membrane Antigen 1 of Plasmodium falciparum [52]. In sharks, IgNARs represent the antibody isotope responsible for antigen-driven immune response and the generation of high affinity antibodies as the consequence of rapid somatic hyper-mutation. Therefore, the authors simulated the natural mutational process by means of error prone PCR using conditions that introduced a single mutation in the whole sequence of the binder previously recovered by conventional panning. This approach allowed for the identification of more affine variants that differed from the original NAR $\mathrm{V}$ single-domain by having a less rigid structure, a feature that determined a better induced fit for the antibody-antigen complex and explained a slower dissociation rate of the mutants. Co-crystallization results indicated that the antibody's CDR3 loops penetrated deeply into hydrophobic clefts on the antigen surface and allowed for the identification of conserved residues that could be targeted preferentially in order to develop polymorphism-independent binders [53].

Single-domain antibodies can apparently also recognize effectively epitopes of parasite glycoproteins both in diagnostic settings and in vivo. It is the case of a $\mathrm{VHH}$ that binds the Ts14 protein of Taenia solium with subnanomolar affinity [54] and of other VHHs specific for oligomannose residues of the variant surface glycoprotein from Tripanosoma $b$. rhodiense [55-57]. Pan-reactive VHHs against Tripanosoma spp. were successively isolated for developing a rapid flow-cytometric diagnostic system for quantitative assess of the pathogen concentration in blood samples $[57,58]$.

\section{Strategies for virus detection and neutralization}

Also in the case of viruses, recombinant antibodies have been conceived as an inexpensive alternative to IgGs for masking the virion proteins involved in the host receptor binding and thus impairing the subsequent infection in vivo [59]. Single-domain antibodies possess a large protruding loop corresponding to the CDR3 and this structural feature represents an advantage over conventional antibodies in reaching the typically cryptic viral epitopes responsible for host recognition, similarly to what has been observed in the case of $\mathrm{VHH}$ competitive inhibition of the enzymatic catalytic site [60]. On the other hand, each virion usually contains tens of such epitope copies. Although it is true that conventional IgGs have no direct access to such hidden epitopes, their large dimension can increase virus neutralization by steric hindrance. To overcome the dimension limitation of VHHs and improve their neutralizing capacity in vitro and in vivo, their mass was increased by conjugation with immunoglobulins or inducing their Nglycosylation by providing suitable residues and successive expression in yeast [61-63]. The approach of defining the residues for $\mathrm{N}$-glycosylation by mutagenesis should avoid specificity and affinity loss for the antigen due to paratope modification and reduced epitope accessibility. Nevertheless, the effectiveness of N-glycosylation for in vivo applications is still to be demonstrated because the large mannosylated carbohydrates synthetized by yeast are actively bound by liver receptors leading to fast $\mathrm{VHH}$ clearance.

The options for rendering single-domain fragments effective in human therapy described above are crucial in view of the fact that an increasing number of binders specific for viruses have been isolated, characterized, and successfully used in vitro and in animal models. For example, an effective diagnostic assay based on llama single-domains for identifying independently four different variants of the Marburg virus was delivered in three working weeks [64]. In this case, the availability of a semi-synthetic library enabled the reduction of the time necessary for the selection procedure, providing the evidence that reliable diagnostic immunoassays based on recombinant antibodies can be optimized during the initial phase of an infective outbreak.

VHHs selected using the group A rotavirus-conserved VP6 inner capsid protein are yet another example of efficacy of antibody fragments in neutralizing the virus and in protecting mice from diarrhea $[65,66]$, where conventional antibodies had a modest effect. Using a strategy similar to that used for bacterial pathogens, VHHs raised against rotavirus were expressed on the surface of lactobacilli and orally administrated in a mouse model $[67,68]$. Severity and duration of the disease were significantly shortened as a consequence of a decrease in the viral load. An increase in the variety and availability of expression cassettes for the secretion or surface display of $\mathrm{VHH}$ antibodies should boost this approach for the protection from virus and bacteria infections [68].

Furthermore, VHHs and NAR Vs resulted effective in detecting poliovirus and inhibiting its replication in vitro $[69,70]$, in binding vaccinia virus [71], and in preventing the assembly and secretion of hepatitis B virions in cellular models by the expression of engineered NAR V and $\mathrm{VHH}$ fragments directed against the cellular endoplasmic reticulum [72-74].

The inhibition of viral secretion using conventional antibodies has not been attempted in mammals because of the technical complexity, but it is becoming feasible using VHHs expressed as intrabodies. They can inhibit the multimerization of the HIV-1 Rev protein by 
binding to the target protein, sequestering it in the cytoplasm, and impairing the HIV-1 replication [75]. The cell uptake of the same virus is impaired by the small drug AMD3100 that acts as an antagonist for the CD4activated co-entry receptor CXCR4. Conventional antibodies with the same function had previously been selected with the aim of isolating receptor antagonists with longer half-life than AMD3100, but they did not block sufficiently the virus-receptor recognition. As an alternative, anti-CXCR4 VHHs have been selected by competitive elution with the natural binder CXCL12 and successively proved to compete with AMD3100. Such VHHs behave as competitive antagonists and potently inhibit the virus uptake [76]. The strategy aimed at inhibiting the HIV-1 infection using VHHs that recognize envelope proteins and neutralize the virions by competing with the main cellular receptor CD4 [77-79] is conceptually similar. Finally, nanobodies have been also used to bind intracellularly the multifunctional Mf1 domain of the IRF-1 tumor suppressor with the idea of regulating this viral infection-stimulated regulative protein [80].

Single-domain antibodies were also successfully used for preparing piezoimmunosensors for the detection of HIV-1 virions [81]. The possibility of displaying at high density and controlling the orientation of these binders on the sensor surfaces strongly increases the method sensitivity.

Finally, the engineering of single-domain antibodies into multivalent anti-viral molecules have been proved to increase the neutralizing action against and to reduce the infectivity of Synctyal, Rabies and influenza viruses $[82,83]$. The simultaneous targeting of different epitopes of the same virus seems a promising alternative to increased avidity provided by multivalent display of the same antibody [83].

\section{Toxin identification and detoxification}

The use of single-domain antibodies for toxin identification and neutralization has increased exponentially in the last two years. Two are the main reasons for the success, namely the possibility to use pre-immune libraries and the opportunity to have a scaffold structurally very stable, but extremely suitable for engineering application-specific modification.

VHH stability is crucial when harsh processing conditions, such as elevated temperatures, high detergent and reducing agent concentrations, or denaturing conditions, are used [51,84-86]. Specifically, toxic prolamins can be effectively extracted for quantification only in the presence of a solvent containing ethanol, 2-mercaptoethanol and guanidinium chloride. Conventional antibodies do not withstand these denaturing conditions and, therefore, are not available for immunological test.
On the contrary, it was possible to select solvent-compatible VHHs with increased stability due to an introduction of extra disulfide bonds that constrained the CDR3 flexibility [84]. N-glycosylation is another parameter that allows the antibody stability tuning and can improve the antibody effectiveness in vivo. Similarly to what has been observed in the case of anti-virus singledomain antibodies, $\mathrm{N}$-glycosylation increased the neutralizing capacity of VHHs against the E. coli heat-labile toxin in a cell model. Such an effect was attributed to the larger mass of the antibody that blocks simultaneously more than one of the five receptor-binding sites present on each toxin molecule [63].

Parallel panning of one-pot libraries yielded single domain antibodies in both $\mathrm{VHH}$ and NAR V format specific for ricin, cholera toxin, and staphylococcal enterotoxin B $[71,87,88]$. These studies demonstrated that pre-immune libraries can be used for rapid generation of antibodies against a large number of harmful antigens and that the single-domain antibody stability is beneficial for increasing their shelf life in diagnostic applications. Furthermore, the troublesome low sensitivity of single domain antibodies in immunological tests due to their monovalency could be overcome by using phage-displayed and not purified antibodies. This method allows the signal amplification by detecting several copies of phage-coating proteins in every single antibody-toxin binding event [89]. Although conventional IgGs are used preferentially for capturing toxins in microflow cytometry for multiplexed detection [90] and in the preparation of metal nanoparticle resistors for cholera toxin detection [91], single-domain antibodies seem suitable for similar applications [92].

A very interesting application in which single-domain cannot be substituted by conventional antibodies has been recently reported [93]. Salmonella SpvB toxin is secreted directly from the bacteria into the host cell cytoplasm and, consequently, is not accessible for extracellular antibodies. However, VHHs raised against the toxin can be expressed and maintain their functionality and specificity as intrabodies. They block the toxin at a molar ratio of 1:1 and prevent its pathological consequences at cellular level.

VHHs outperformed conventional antibodies also when used for the preparation of bivalent and bispecific constructs used for the in vivo neutralization of the AahI'/AahII scorpion toxins [94-96]. Multivalency induced by $\mathrm{VHH}$ polymerization [97-99] was exploited also to increase the neutralizing capacity of antibodies against the $E$. coli verotoxin 1 [100], alpha-cobrotoxin [101], and C. difficile toxin A [102], whereas the reduced production costs and the high density at which $\mathrm{VHH}$ can be coupled to resin substrates made feasible the preparation of hemofiltration columns for removing 
toxin shock syndrome toxin 1 from plasma to alleviate staphylococcal-induced sepsis [103,104]. Also an unconventional mouse $\mathrm{VH}$ resulting from an incomplete $\mathrm{scFv}$ antibody has been isolated and characterized because of its anti-toxin potentialities. In particular, it appeared to be a functional anti-idiotypic antibody for the HM-1 killer toxin with a higher affinity than $\mathrm{scFv}$ antibodies recovered from the same library for the neutralizing monoclonal antibody [105].

Toxins such as ricin and botulinum neurotoxin are classified as bioweapons and have been the object of a particular attention. In a project aimed at isolating antiricin antibodies, the panning protocol was first optimized using the toxin immobilized on the surface of microspheres [106]. The isolated VHHs were as effective as conventional monoclonal antibodies in blocking the ricin biological activity [107], but were superior in terms of specificity [108].

The majority of the publications on the toxin topic concerns the Clostridium botulinum neurotoxin (BoNT) because it causes frequently fatal disease and there is no drug able to reverse the symptoms once the toxin has entered the neuron. The interest in developing singledomain antibodies against BoNT is primarily motivated by the stability of these molecules even when they are expressed in the cytoplasm as intrabodies, facilitating not only diagnostic [109-111], but also therapeutic applications. Flow cytometry sorting of pre-immune, yeast displayed antibodies in $\mathrm{VHH}$ format allowed the isolation of anti-BoNT single-domains against the toxin light chain that inhibited the toxin protease activity in vitro and had structural features compatible for their production in the host cell cytoplasm [85]. Singledomain antibodies that inhibit the toxin protease activity by occupying the enzymatic cleft were also recovered from a mixed $\mathrm{VH} / \mathrm{VHH}$ library [35], whereas VHHs isolated from an immune library retained their toxin inhibitory properties also when expressed in mammalian neuronal cell cytosol [112].

\section{Hapten targeting}

Small molecules are not expected to be targeted efficiently by single-domain antibodies since they posses a limited number of conformational epitopes suitable for recognition by protruding single-domain paratopes. Nevertheless, there are several examples showing that VHHs can be exploited for detecting haptens as different as herbicides, caffeine, mycotoxins, trinitrotoluene, steroids and therapeutic drugs [113-120] for this antibody class can interact with its targets adopting different binding patterns [121]. For instance, the CDR1 loop provides a strong interaction for the azo-dye Reactive Red 6 [122], CDR2 and a framework residue contribute to the binding of Reactive Red 1 [123], whereas a non-conventional, substrate-dependent dimerization mechanism is involved in the binding of caffeine and its metabolites [124]. The stability of single-domain antibodies expressed in the cytoplasm has been used to induce their cellular accumulation as an effective tool for neutralizing the mycotoxin 15-acetyldeoxynivaleol in vivo [119].

\section{Reagents for immunodetection, purification and bioseparation}

As an affinity-based technique, immunopurification presents some theoretical advantages over chromatographic methods based on chemical and physical properties. It can simplify complex multi-step procedures to a single step protocol, reducing production costs and time. Consequently, it can improve yields and limit potential product degradation. Nevertheless, immunopurification performed with conventional antibodies often requests extreme elution conditions that can damage the purified product. The advantages offered by single-domain antibody fragments in immunochromatography have been demonstrated for the first time by Verheesen et al. [125]. Their monomeric nature facilitated the elution of the target protein, whereas their physical stability and effective refolding allowed the regeneration of the column under harsh cleaning conditions for more than 2000 times. Mild elution conditions are necessary to preserve product structure and activity. From this perspective, panning $\mathrm{VHH}$ libraries has resulted as being an optimal solution since binders can be selected not only based on their specificity, but also on their elution features. In this way, unstable proteins such as serum factor VIII and alpha-1 antitrypsin have been immunopurified successfully using $\mathrm{VHH}$ antibodies for their capture and elution at neutral $\mathrm{pH}[126,127]$. In a comparative assay with longer antibody constructs and complete IgGs, affinity columns prepared with VHHs enabled higher yields, probably because of the higher density at which they are bound to the matrix [128]. Such VHH-based affinity columns have found their applications for both purifying specific components from heterogeneous material [103,129-131] and for depleting very abundant proteins from samples in which it is necessary to detect the variation of scarcely represented polypeptides. It is the case of the platforms developed for the removal of IgG and human serum albumin from plasma before processing the samples in proteomic assays [132] and of the nanotrap for the purification of GFP-fused proteins from cell homogenates $[133,134]$. VHH-based affinity chromatography resulted also as very effective in removing contaminants such as DNA and virus particles [135]. At the same time, VHHs specific for adeno-associated viruses allowed for the simplification of the purification protocol of these 
molecules from five to one or two steps and for doubling of the final yields [136,137]. Beside the published reports and filed patent applications, a further indication of the single-domain antibody reliability as reagents for immunopurification can be inferred by the list of $\mathrm{VHH}-$ based affinity resins developed by biotech companies $[138,139]$.

The small dimension $(15 \mathrm{KDa}, 4 \times 2.5 \times 3 \mathrm{~nm})$ of single-domain antibodies and the possibility to produce them as recombinant proteins fused to suitable tags make them inexpensive binders that can be easily oriented at high density on capture surfaces such as chips and biosensors or adapted to a large variety of applications such as purification, imaging, immunomicelle and liposome preparation, or immobilization on nanoparticle resistors for the detection of cancer markers and cholera toxin $[81,92,128,140-146]$. A promising utilization strategy considers the $\mathrm{VHH}$ labeling via the 6xHis tag with metastable $(99 \mathrm{~m})$ technetium for application in single-photon emission computed tomography (SPECT), a noninvasive monitoring technique for observing the tumor response to therapy [147-152], but nanobodies have been effectively labeled also with (68)Ga for immuno-positron emission tomography (PET) [153]. In both cases, their elevated tissue penetration and rapid clearance allow for optimal high-contrast, specific localization in vivo in a time significantly shorter than that enabled by using conventional IgGs $[145,154,155]$. Finally, the use of single-domain antibodies doubletagged with gadolinium and near-infrared dye Cy5.5 allowed the simultaneous optical and magnetic resonance imaging of brain tumor vessels [156].

\section{Single-domain antibody fragments as crystallography chaperones and tools for studying protein aggregation and activity regulation}

The possibility of using antibodies to stabilize the conformation of proteins that undergo crystallization trials has been recognized since long time [157-159]. Nevertheless, conventional antibodies and their fragments have limitations due to their bulky mass (IgG and Fab fragment) or low stability (scFv) and, therefore, other molecules have been proposed, such as affibodies, fibronectin, and DARPins [160-162]. Single-domain antibodies seem a logical alternative since they can be produced inexpensively in short time, have a strong binding capacity, reduced mass, demonstrated capacity of providing "induced fit" to the antigen-antibody complex, and they improve crystal packing and X-ray phasing [163-165]. Although VHHs are amenable for simple site-specific incorporation of SeMet into their scaffolds, the fact that co-crystallizing with a single-domain antibody improves the complementary anomalous dispersion data acquisition and gives an ideal template for molecular replacement represents a substantial advantage for structure resolution [163]. Furthermore, VHHs are very flexible in terms of interface shapes [121-124] and, therefore, can adapt to a large variety of epitopes and block intrinsically flexible regions of their antigens [166]. VHHs have also been added directly to the solubilized membrane fraction for binding to and stabilizing the nitric oxide reductase membrane target protein [167] during the purification that resulted in the recovery of the antigen-antibody complex. No condition giving rise to diffracting crystals were found with the enzyme alone, but crystals were obtained in the presence of the VHHs. It has also been demonstrated that VHHs and their corresponding antigens can be coexpressed recombinantly in the same host and co-purified using tags fused to the antibody sequence, simplifying the protocol for producing antigen-antibody complexes [140].

The VHH-dependent approaches led to the resolution of several structures in the last few years [79,167-171]. VHHs seem to favor the formation of crystals of several different forms and to accelerate in a dramatic way the crystallization of recalcitrant protein complexes [168-170]. In the case of the KREPA6 editosome protein in combination with the $\mathrm{Nb} 5$ and $\mathrm{Nb} 15 \mathrm{VHHs}$, all crystal contacts are obtained by the single-domain co-chaperones [170], while the role of VHHs is mainly to keep the flexible loop connecting the N1 and N2 domains of GspD in a fixed conformation [168] and to form stabilizing layers between layers of EpsI:EpsJ heterodimers [169]. Furthermore, although CDR3 is usually the major component involved in the antigen binding and crystal chaperoning [172], a feature deriving probably from its structural flexibility [79], in some cases CDR2 and even framework 3 can become pivotal chaperoning elements [170].

In the case of a study of the $G$ protein coupled $\beta_{2}$ adrenoreceptor, the VHH characteristics were useful at different levels. Whereas the crystallization of the inactive state of different members belonging to such receptor class has been achieved, the efforts to obtain a crystal of the receptor active state were frustrated due to receptor instability in the absence of $\mathrm{G}$ proteins. On the other hand, the receptor- $G$ protein complex is unstable in the presence of the detergent necessary for the receptor stabilization. Therefore, suitable agonists were necessary for this aim. A high-affinity VHH agonist of the G protein was successfully identified by panning, its binding to the receptor was stable, maintained it in its active form during the crystallization trial functioning as a substrate agonist, and allowed the structure resolution operating as a crystallization chaperone [171].

VHHs also proved as being particularly useful for studying the intermediates of aggregation-prone 
polypeptides such as in the case of prion protein [173] and of the amyloidogenic fragments [174]. Single domain antibodies of different origin enabled the elucidation of the variety of morphologically distinct $A \beta$ aggregates, blocking their polymerization development into non-toxic intermediates, and the clarification of the plausible mechanism of amyloidogenic protein self-association [175-180]. Specifically, domain swapping appears as a plausible self-association mechanism for amyloidogenic $\beta 2$-microglobulin. Protein dimers undergoing swapping unmask amyloidogenic sequences that fold into two-stranded antiparallel $\beta$-sheet. Self-association of the sheet $\beta$-strands can provide the elongation mechanism by which large intermolecular $\beta$-sheets are built [179]. The first X-ray crystallographic structure of the complete $A \beta_{18-41}$ fragment has been obtained by an innovative approach that may be of general interest for the study of tricky short peptides. The sequence corresponding to the fragment has been cloned inside the CDR3 of an IgNAR $\mathrm{V}$ and the chimeric protein expressed [180]. In such a way, amyloidogenic oligomerization was allowed through the direct contact of the exposed $A \beta$ fragments, but its uncontrolled development prevented by the formation of an IgNAR cage. Crystallographic data confirmed the formation of an $A \beta$ fragment-mediated tight tetramer in which the fine molecular mechanisms of the interaction could be observed and described.

The structures inferred from crystallographic datasets were also useful for the understanding of the mechanism by which a nanobody constrained the dehydrofolate reductase enzyme in its occluded form by binding it in a region adjacent to the active site. Such allosteric control of the enzyme activity raised hyperbolic inhibition kinetics and induced a conformational rearrangement of the whole enzyme structure [181]. Structural data were also necessary to explain the allosteric inhibition mechanism of the botulinum neurotoxin induced by another $\mathrm{VHH}$ [85]. In this case, it was possible to recognize that the antibody epitope corresponded to the $\alpha$ exosite of the neurotoxin. This information has practical potentials since it identifies a target for the development of inhibitory small-molecule drugs.

Sometimes, the VHH-dependent allosteric enzyme modulation becomes extremely complex as illustrated by the case of the interaction between single-domains and the nucleoside hydrolase from Trypanosoma vivax [182]. The same antibody inhibited the catalytic pathway, but increased the product release rate and showed inhibitory or simulating behavior according to the substrate affinity for the enzyme. Another example of a complex modulation has been provided by the antihuman protein kinase $\mathrm{C}$ for which two sets of VHHs were isolated by panning immune libraries. All the five isolated $\mathrm{VHHs}$ were specific exclusively for a single isozyme (PKC $)$ ), and surprisingly, whereas three of them increased the kinase activity in a concentration-dependent manner, the remaining two inhibited the isozyme [183]. Taken together, these data indicate that VHHs possess not solely of a large array of paratope surfaces but that, beside their known capacity to block the enzyme active sites $[60,184]$, they have alternative binding mechanisms involving different structural regions that are suitable for tuning their antigen-binding activity.

\section{Technical considerations-Conclusions}

The number of reports dealing with single-domain antibody applications in different fields clearly indicates that this class of immunoreagents represents an important tool for research as well as biotechnological uses (Table 1). Furthermore, the described examples show that single-domain antibodies are complementary rather than alternative with respect to conventional antibodies in the sense that perform functions not possible to accomplish with IgGs.

However, there are several technical issues that still need to be defined in a systematic way, at the recombinant antibody panning level as well as at the level of binder production strategies. For instance, the praxis indicates that one-pot libraries can deliver highly affine and specific antibodies [29,85,113,185-187], although somatic maturation was considered essential to obtain reliable binders. Moreover, it has been emphasized that non-immune library dimensions and display system were crucial for obtaining valid recombinant antibodies, but E. coli, yeast and ribosome display, even though successful at simplifying the panning and screening steps by means of flow-cytometric clone separation [188-191], did not perform better than small phage display libraries and recently even minimal libraries have proved to be potent means of selecting lead antibodies [192]. For a long time, an elevated affinity has been considered an absolute necessity, but now we know that it is important

Table 1 Available literature relative to the different biotechnological applications analyzed in the review

\begin{tabular}{cc}
\hline Field of Application & References \\
\hline Bacteria and Phages & $20,38-41,43-50$ \\
\hline Fungi and Protozoans & $51-58$ \\
\hline Viruses & $60-83$ \\
\hline Toxins & $35,63,71,84-89,92-112$ \\
\hline Haptens & $113-124$ \\
\hline Immunodetection, Immunopurification, \\
Bioseparation & $81,92,125-156$ \\
\hline Crystallography, Aggregates, Enzyme \\
regulation
\end{tabular}


for in vitro application, whereas it can correlate inversely with appropriate tumor penetration in vivo $[193,194]$.

Finally, several applications in chromatography, bioseparation, crystallography, or therapy need large amounts of recombinant antibodies and their fusion derivates, but their production technology has not improved significantly, although innovations concerning their expression in both bacterial periplasm $[195,196]$ and in eukaryotic systems have been introduced $[65,197]$. However, a breakthrough seems to have arrived now with the advent of a technology enabling the cytolasmic accumulation of disulfide bond-dependent proteins. This approach aims at inducing the disulfide bond formation by co-expressing a sulfhydryl oxidase instead of disrupting the reducing pathways in the cytosol $[198,199]$ and resulted in yields of $\mathrm{VHH}$-fusion constructs in the range of several tens of $\mathrm{mg} / \mathrm{L}$ culture [200].

Given the excellent qualitative performance of singledomain antibodies and their advantages in terms of structural features, stability, and production costs, a question remains to be answered as to why it has taken almost twenty years for them to become largely popular in the scientific community. Probably two reasons are the main responsible for this slow technology acknowledgment. The pretty restrictive intellectual property policy introduced by the inventor institutions with the "Hamers patents" that first defined the field has been extremely successful in boosting the spin-off companies funded to exploit the discovery, but it has probably prevented other actors from participating in the development. The second reason concerns the fact that for a long time there was only a minimal availability of those application-friendly tools for research and diagnostics that are necessary for making new technologies appealing to non-specialist researchers [201]. With the original patents expiring in the next few years and the recent accessibility of new libraries, protocols, and vectors suitable for different immunoapplications, we expect an increase of the interest of both research and industry for this class of recombinant antibodies in the near future.

\section{Acknowledgements}

The author wishes to thank Alicja Gruszka for her stimulating comments.

\section{Competing interests}

The author declares that they have no competing interests.

Received: 30 March 2011 Accepted: 9 June 2011 Published: 9 June 2011

\section{References}

1. Gebauer M, Skerra A: Engineered protein scaffolds as next-generation antibody therapeutics. Curr Opin Chem Biol 2009, 13:245-255.

2. Kontermann RE: Alternative antibody formats. Curr Opin Mol Ther 2010, 12:176-183.

3. Editorial: Recent patent applications in antibody fragments. Nat Biotechnol 2009, 27:41.
4. Wesolowski J, Alzogaray $V$, Reyelt J, Unger $M$, Juarez K, Urrutia M, Cauerhff A, Danquah W, Rissiek B, Scheuplein F, Schwarz N, Adriouch S, Boyer O, Seman M, Licea A, Serreze DV, Goldbaum FA, Haag F, KochNolte F: Single domain antibodies: promising experimental and therapeutic tools in infection and immunity. Mol Microbiol Immunol 2009, 198:157-174.

5. Schrama D, Reisfeld RA, Becker JC: Antibody targeted drugs a cancer therapeutics. Nat Rev 2006, 5:147-159.

6. Chames P, Van Regenmortel M, Weiss E, Baty D: Therapeutic antibodies: successes, limitations and hopes for the future. Brit J Pharmacol 2009, 157:220-233.

7. Nanduri V, Bhunia AK, Tu S-I, Paoli GC, Brewster JD: SPR biosensor for the detection of $L$. monocytogenes using phage-displayed antibody. Biosens Bioelectron 2007, 23:248-252.

8. Abulrob A, Sprong H, Van Bergen en Henegouwen P, Stanimirovic D: The blood-brain barrier transmigrating single domain antibody: mechanism of transport and antigenic epitopes in human brain endothelial cells. $J$ Neurochem 2005, 95:1201-1214.

9. Iqbal U, Trojahn U, Albaghdadi H, Zhang J, O'Connor-McCourt M, Stanimirovic D, Tomanek B, Sutherland G, Abulrob A: Kinetic analysis of novel mono-and multivalent $\mathrm{VHH}$-fragments and their application for molecular imaging of brain tumours. Br J Pharmacol 2010, 160:1016-1028.

10. Jobling SA, Jarman C, The M-M, Holmberg N, Blake C, Verhoeyen E: Immunomodulation of enzyme function in plants by single-domain antibody fragments. Nat Biotechnol 2003, 21:77-80.

11. Klooster R, Eman R, le Duc Q, Verheesen P, Verrips T, Roovers RC, Post JA: Selection and characterization of KDEL-specific VHH antibody fragments and their application in the study of ER resident protein expression. J Immunol Meth 2009, 342:1-12.

12. Schornack S, Fuchs R, Huitema E, Rothbauer U, Lipka V, Kamoun S: Protein mislocalization in plant cells using a GFP-binding chromobody. Plant J 2009, 60:744-754.

13. Kirchhofer A, Helma J, Schmidthals K, Frauer C, Cui S, Karcher A, Pellis M, Muyldermans S, Casas-Delucchi CS, Cardoso MC, Leonhardt H, Hopfner KP Rothbauer U: Modulation of protein properties in living cells using nanobodies. Nat Struct Mol Biol 2010, 17:133-138.

14. Perrucchini C, Pecorari F, Bourgeois J-P, Duyckaerts C, Rougeon F, Lafaye P: Llama VHH antibody fragments against GFAP: better diffusion in fixed tissues than classical monoclonal antibodies. Acta Neuropathol 2009, 118:685-695.

15. Alvarez-Rueda N, Ladjemi MZ, Behar G, Corgnac S, Pugniere M, Roquet F, Bascoul-Mollevi C, Baty D, Pèlegrin A, Navarro-Teulon I: A llama single domain anti-idiotypic antibody mimicking HER2 as a vaccine: Immunogenicity and efficacy. Vaccine 2009, 27:4826-4833.

16. Huang L, Muyldermans S, Saerens D: Nanobodies ${ }^{\oplus}$ : proficient tools in diagnostic. Expert Rev Mol Diagn 2010, 10:777-785.

17. Barthelemy PA, Raab H, Appleton BA, Bond CJ, Wu P, Wiesmann C, Sidhu SS: Comprehensive analysis of the factors contributing to the stability and solubility of autonomous human VH domains. J Biol Chem 2008, 283:3639-3554

18. Jespers L, Schon O, James LC, Veprintsev D, Winter G: Crystal structure of HEL4, a soluble, refoldable human VH single domain with germ-line scaffold. J Mol Biol 2004, 337:893-903.

19. Bond CJ, Marsters JC, Sidhu SS: A structure-based database of antibody variable domain diversity. J Mol Biol 2003, 332:643-655.

20. To R, Hirama T, Arbabi-Ghahroudi M, MacKenzie R, Wang P, Xu P, Ni F, Tanha J: Isolation of monomeric human VHs by a phage selection. J Biol Chem 2005, 280:41395-41403.

21. Chen W, Zhu Z, Feng Y, Xiao X, Dimitrov DS: Construction of a large phage-displayed human antibody domain library with a scaffold based on a newly identified highly soluble, stable heavy chain variable domain. J Mol Biol 2008, 382:779-789.

22. Jespers L, Schon O, Famm K, Winter G: Aggregation-resistant domain antibodies selected on phage by heat denaturation. Nat Biotechnol 2004, 22:1161-1165.

23. de Marco A: A step ahead: combining protein purification and correct folding selection. Microb Cell Fact 2004, 3:12.

24. Kortt AA, Guthrie RE, Hinds MG, Power BE, Ivancic N, Caldwell JB, Gruen LC, Norton RS, Hudson PJ: Solution properties of Escherichia coli-expressed VH domain of anti-neuraminidase antibody NC41. J Prot Chem 1995, 14:167-178. 
25. Ward ES, Güssow D, Griffiths AD, Jones PT, Winter G: Binding activities of a repertoire of single immunoglobulin variable domains secreted from Escherichia coli. Nature 1989, 341:544-546.

26. Reiter Y, Schuck P, Boyd LF, Plaskin D: An antibody single-domain phage display library of a native heavy chain variable region: isolation of functional single-domain VH molecules with a unique interface. $J \mathrm{Mol}$ Biol 1999, 290:685-698.

27. Cai $X$, Garen A: A melanoma-specific VH antibody cloned from a fusion phage library of a vaccinated melanoma patient. Proc Natl Acad Sci USA 1996, 93:6280-6285.

28. Tanha J, Dubue G, Hirama T, Narang SA, MacKenzie CR: Selection by phage display of llama conventional $V_{H}$ fragments with heavy chain antibody $\mathrm{V}_{\mathrm{H}} \mathrm{H}$ properties. J Immunol Methods 2002, 263:97-109.

29. Monegal A, Ami D, Martinelli C, Huang H, Aliprandi M, Francavilla C, Ossolengo G, de Marco A: Immunological applications of single domain llama recombinant antibodies isolated from a naïve library. Prot Engineer Des Sel 2009, 22:273-280.

30. Zou X, Osborn MJ, Bolland DJ, Smith JA, Corcos D, Hamon M, Oxley D, Hutchings A, Morgan G, Santos F, Kilshaw PJ, Taussig MJ, Corcoran AE, Brüggemann $\mathrm{M}$ : Heavy chain-only antibodies are spontaneously produced in light chain-deficient mice. J Exp Med 2007, 204:3271-3283.

31. Deschacht N, De Groeve K, Vincke C, Raes G, De Baetselier P, Muyldermans: A novel promiscuous class of camelid single-domain antibody contributes to the antigen-binding repertoire. J Immunol 2010, 184:5696-5704.

32. Tanaka T, Lobato MN, Rabbitts TH: Single domain intracellular antibodies: A minimal fragment for direct in vivo selection of antigen-specific intrabodies. J Mol Biol 2003, 331:1109-1120.

33. Tanaka T, Sewell H, Waters S, Phillips SE, Rabbits TH: Single domain intracellular antibodies from diverse libraries: emphasizing dual functions of LMO2 protein interactions using a single $\mathrm{VH}$ domain. J Biol Chem 2011, 286:3707-3716.

34. Kastelic D, Frkovič-Grazio S, Baty D, Truan G, Komel R, Pompon D: A singlestep procedure of recombinant library construction for the selection of efficiently produced llama VH binders directed against cancer markers. J Immunol Meth 2009, 350:54-62.

35. Thanongsaksrikul J, Srimanote P, Maneewatch S, Choowongkomon K, Tapchaisri P, Makino S, Kurazono H, Chaicumpa W: A VHH that neutralizes the zinc metalloproteinase activity of botulinum neurotoxin type A. J Biol Chem 2010, 285:9657-9666.

36. Cossins AJ, Harrison S, Popplewell AG, Gore MG: Recombinant production of a VL single domain antibody in Escherichia coli and analysis of its interaction with peptostreptococcal protein L. Prot Expr Purif 2007, 51:253-259.

37. Martsev SP, Tsybovsky YI, Stremovskiy OA, Odintsov SG, Balandin TG Arosio P, Kravchuk ZI, Deyev SM: Fusion of the antiferritin antibody VL domain to barnase results in enhanced solubility and altered $\mathrm{pH}$ stability. Protein Eng Des Sel 2004, 17:85-93.

38. Ryan S, Kell AJ, van Faassen H, Tay L-L, Simard B, Mackenzie R, Gilbert M, Tanha J: Single-domain antibody-nanoparticles: Promising architectures for increased Staphylococcus aureus detection specificity and sensitivity Bioconjugate Chem 2009, 20:1966-1974.

39. Huang P-J, Tay L-L, Tanha J, Ryan S, Chau L-K: Single-domain antibodyconjugated nanoaggregate-embedded beads for targeted detection of pathogenic bacteria. Chem Eur J 2009, 15:9330-9334.

40. Harmsen MM, van Solt CB, Hoogendoom A, van Zijederveld FG, Niewold TA, van der Meulen J: Escherichia coli F4 fimbriae specific llama single-domain antibody fragments effectively inhibit bacterial adhesion in vitro but poorly protect against diarrhoea. Vet Microbiol 2005, 111:89-98.

41. Krüger $C$, Hultberg $A$, Marcotte $H$, Hermans $P$, Bezemer $S$, Frenken LGJ, Hammarström L: Therapeutic effect of llama derived VHH fragments against Streptococcus mutans on the development of dental caries. Appl Microbiol Biotechnol 2006, 72:732-737.

42. Krüger C, Hu Y, Pan Q, Marcotte H, Hultberg A, Delwar D, van Dalen PJ, Pouwels PH, Leer RJ, Kelly CG, van Dollenweerd C, Ma JK, Hammarström L: In situ delivery of passive immunity by lactobacilli producing singlechain antibodies. Nat Biotechnol 2002, 20:702-706.

43. Krüger C, Hultberg A, van Dollenweerd C, Marcotte H, Hammarström L: Passive immunization by lactobacilli expressing single-chain antibodies against Streptococcus mutans. Mol Biotechnol 2005, 31:221-231.
44. Vandenbroucke K, de Haard H, Beirnaert E, Dreier T, Lauwereys M, Huyck L, Van Huysse J, Demetter P, Steidler L, Remaut E, Cuvelier C, Rottiers P: Orally administrated $L$. lactis secreting an anti-TNF nanobody demonstrate efficacy in chronic colitis. Mucosal Immunol 2010, 3:49-56.

45. Szynol A, de Soet JJ, Sieben-van Tuyl E, Bos JW, Frenken LG: Bacterial effect of a fusion protein of llama heavy-chain antibodies coupled to glucose oxidase on oral bacteria. Antimicrob Agents Chemother 2004, 48:3390-3395.

46. Harmsen MM, van Solt CB, van Zijederveld-van Bemmel AM, Niewold TA, van Zijederveld FG: Selection and optimization of proteolytically stable Ilama single-domain antibody fragments for oral immunotherapy. App/ Microbiol Biotechnol 2006, 72:544-551.

47. Conrath $K E$, Lauwereys M, Galleni M, Matagne A, Frere JM, Kinne J, Wyns L, Muyldermans S: Beta-lactamase inhibitors derived from single-domain antibody fragments elicited in the Camelidae. Antimicrob Agents Chemoter 2001, 45:2807-2812.

48. Ledeboer AM, Bezemer S, De Haard HJ, Schaffers IM, Verrips $C T$, van Vliet, Düsterhöft EM, Zoon P, Moineau S, Frenken LG: Preventing phage lysis of Lactococcus lactis in cheese production using a neutralizing heavy-chain antibody fragment from llama. J Dairy Sci 2002, 85:1376-1382.

49. de Haard HJ, Bezemer S, Ledeboer AM, Müller WH, Boender PJ, Moineau S, Coppelmans MC, Verkleij AJ, Frenken LG, Verrips CT: Llama antibodies against a lactococcal protein located at the tip of the phage tail prevent phage infection. J Bacteriol 2005, 187:4531-4541.

50. Hultberg A, Tremblay D, de Haard HJ, Verrips T, Moineau S, Hammarström L, Marcotte H: Lactobacilli expressing llama VHH fragments neutralize Lactococcus phages. BMC Biotechnol 2007, 7:58.

51. Dolk E, van der Vaart M, Hulsik DL, Vriend G, de Haard HJ, Spinelli S, Cambillau C, Frenken L, Verrips T: Isolation of llama antibody fragments for prevention of dandruff by phage display in shampoo. Appl Environ Microbiol 2005, 71:442-450.

52. Nuttall SD, Humbestone KS, Krishnan UV, Carmichael JA, Doughty L, Hattarki M, Coley AM, Casey JL, Anders RF, Foley M, Irving RA, Hudson PJ: Selection and affinity maturation of IgNAR variable domains targeting Plasmodium falciparum AMA1. Proteins 2004, 55:187-197.

53. Henderson KA, Streltsov VA, Coley AM, Dolezal O, Hudson PJ, Batchelor AH, Gupta A, Bai T, Murphy VJ, Anders RF, Foley M, Nuttall SD: Structure of an IgNAR-AMA1 complex: targetig a conserved hydrophobic cleft broadens malarial strain recognition. Structure 2007, 15:1452-1466.

54. Deckers N, Saerens D, Kanobana K, Conrath K, Victor B, Wernery U, Vercruysse J, Muyldermans S, Dorny P: Nanobodies, a promising tool for species-specific diagnosis of Taenia solium cysticercosis. Int J Parasitol 2009, 39:625-633.

55. Stijlemans B, Conrath K, Cortez-Retamozo V, Van Xong H, Wyns L, Senter P, Revets H, De Baetselier P, Muyldermans S, Magez S: Efficient targeting of conserved cryptic epitopes of infectious agents by single domain antibodies. J Biol Chem 2004, 279:1256-1261.

56. Baral TN, Magez S, Stijlemans B, Conrath K, Vanhollebeke B, Pays E, Muyldermans $S$, De Baetselier P: Experimental therapy of African trypanosomiasis with a nanobody-conjugated human trypanolytic factor. Nat Med 2006, 12:580-584.

57. Saerens D, Stijlemans B, Baral TN, Nguyen Thi GT, Wernery U, Magez S, De Baetselier P, Muyldermans S, Conrath K: Parallel selection of multiple antiinfectome nanobodies without access to purified antigens. J Immunol Meth 2008, 329:138-150.

58. Antoine-Moussiaux N, Saerens D, Desmecht D: Flow cytometry enumeration of parasitemia and hematologic changes in trypanosomeinfected mice. Acta Trop 2008, 107:139-144.

59. Parren PV, Burton DR: The antiviral activity of antibodies in vitro and in vivo. Adv Immunol 2001, 77:195-262.

60. Lauwereys M, Arbabi Ghahroudi M, Desmyter A, Kinne J, Hölzer W, De Genst $E$, Wyns $L$, Muyldermans S: Potent enzyme inhibitors derived from dromedary heavy-chain antibodies. EMBO J 1998, 17:3512-3520.

61. Harmsen MM, Van Solt CB, Fijten HPD, Van Setten MC: Prolonged in vivo residence times of llama single-domain antibody fragments in pigs by binding to porcine immunoglobulins. Vaccine 2005, 23:4926-4934.

62. Harmsen MM, Van Solt CB, Fijten HPD, Van Keulen L, Rosalia RA, Weerdmeester K, Cornelissen AH, De Bruin MG, Eblé PL, Dekker A: Passive immunization of guinea-pigs with llama single-domain antibody fragments against foot-and-mouth disease. Vet Microbiol 2007, 120:193-206. 
63. Harmsen MM, Van Solt CB, Fijten HPD: Enhancement of toxin-and virusneutralizing capacity of single-domain antibody fragments by $\mathrm{N}$ glcosylation. Appl Microbiol Biotechnol 2009, 84:1087-1094.

64. Sherwood LJ, Osborn LE, Carrion R, Patterson JL, Hayhurst A: Rapid assembly of sensitive antigen-capture assays for Marburg virus, using in vitro selection of llama single-domain antibodies, at biosafety level 4. J Infect Dis 2007, 196:S213-S219.

65. van der Vaart JM, Pant N, Wolvers D, Bezemer S, Hermans PW, Bellamy K, Sarker SA, van der Logt CP, Svensson L, Verrips CT, Hammarström L, van Klinken BJ: Reduction of morbidity of rotavirus induced diarrhoe in mice by yeast produced monovalent llama-derived antibody fragment. Vaccine 2006, 24:4130-4137.

66. Garaicoechea L, Olichon A, Marcoppido G, Wigdorovitz A, Mozgovoj M, Saif $L$, Surrey $T$, Parreño $V$ : Llama-derived single-chain antibody fragments directed to rotavirus VP6 protein possess broad neutralizing activity in vitro and confer protection against diarrhea in mice. J Virol 2008, 82:9753-9764.

67. Pant $N$, Hultberg A, Zhao $Y$, Svensson L, Pan-Hammarström Q, Johansen $K$, Pouwels PH, Ruggeri FM, Hermans P, Frenken L, Boren T, Marcotte H, Hammarström L: Lactobacilli expressing variable domain of llama heavychain antibody fragments (lactobodies) confer protection against rotavirus-induced diarrhea. J Infect Dis 2006, 194:1580-1588.

68. Martin MC, Pant N, Ladero V, Günaydin G, Andersen KK, Alvarez B, Martínez N, Alvarez MA, Hammarström L, Marcotte H: Integrative expression system for delivery of antibody fragments by lactobacilli. Appl Environ Microbiol 2011, 77:2174-2179.

69. Thys B, Schotte L, Muyldermans S, Wernery U, Hassanzadeh-Ghassabeh G, Rombaut B: In vitro antiviral activity of single domain antibody fragments against poliovirus. Antiviral Res 2010, 87:257-264.

70. Thys B, Saerens D, Schotte L, De Bleeser G, Muyldermans S, HassanzadehGhassabeh $G$, Rombaut B: A simple quantitative affinity capturing assay of poliovirus antigens and subviral particles by single-domain antibodies using magnetic beads. J Virol Meth 2011, 173:300-305.

71. Goldman ER, Anderson GP, Liu JL, Delehanty JB, Sherwood LJ, Osborn LE, Cummins LB, Hayhurst A: Facile generation of heat-stable antiviral and antitoxin single domain antibodies from a semisynthetic llama library. Anal Chem 2006, 78:8245-8255.

72. Serruys B, Van Houtte F, Verbrugghe P, Leroux-Roels G, Vanlandschoot P. Llama-derived single-domain intrabodies inhibit secretion of hepatitis $B$ virions in mice. Hepathol 2009, 49:39-49.

73. Serruys B, Van Houtte F, Farhoudi-Moghadam A, Leroux-Roels G, Vanlandschoot P: Production, characterization and in vitro testing of HBcAg-specific VHH intrabodies. J Gen Virol 2010, 91:643-652.

74. Walsh R, Nuttall S, Revill P, Colledge D, Cabuang L, Soppe S, Dolezal O, Griffiths K, Bartholomeusz A, Locarnini S: Targeting the hepatitis B virus precore antigen with a novel IgNAR single variable domain intrabody. Virol 2011, 411:132-141.

75. Vercruysse T, Pardon E, Vanstreels E, Steyaert J, Daelemans D: An intrabody based on a llama single-domain antibody targeting the $\mathrm{N}$-terminal ahelical multimerization domain of HIV-1 Rev prevents viral production. J Biol Chem 2010, 285:21768-21780.

76. Jähnichen S, Blanchetot C, Maussang D, Gonzalez-Pajuelo M, Chow KY, Bosch L, De Vrieze S, Serruys B, Ulrichts H, Vandevelde W, Saunders M, De Haard HJ, Schols D, Leurs R, Vanlandschoot P, Verrips T, Smit MJ: CXCR4 nanobodies (VHH-based single variable domains) potently inhibit chemotaxis and HIV-1 replication and mobilize stem cells. Proc Natl Acad Sci USA 2010, 107:20565-20570.

77. Forsman A, Beirnaert E, Aasa-Chapman MMI, Hoorelbeke B, Hijazi K, Koh W, Tack V, Szynol A, Kelly C, McKnight A, Verrips T, de Haard H, Weiss RA: Llama antibody fragments with cross-subtype human immuodeficency virus type 1 (HIV-1)-neutralizing properties and high affinity for HIV-1 gp120. J Virol 2008, 82:12069-12081.

78. Koh WW, Steffensen S, Gonzalez-Pajuelo M, Hoorelbeke B, Gorlani A, Szynol A, Forsman A, Aasa-Chapman MM, de Haard H, Verrips T, Weiss RA: Generation of a family-specific phage library of llama single chain antibody fragments that neutralize HIV-1. J Biol Chem 2010, 285:19116-19124.

79. Hinz A, Hulsik DL, Forsman A, Koh WW, Belrhali H, Gorlani A, de Haard H, Weiss RA, Verrips T, Weissenhorn W: Crystal structure of the neutralizing llama VHH D7 and its mode of HIV-1 gp120 interaction. PLoSOne 2010, 5: e10482.
80. Möller A, Pion E, Narayan V, Ball KL: Intracellular activation of interferon regulatory factor- 1 by nanobodies to the multifunctional (Mf1) domain. $J$ Biol Chem 2010, 285:38348-38361.

81. Ferreira GN, Encarnacao JM, Rosa L, Rodrigues R, Beyner R, Barrento S, Pedro L, Aires da Silva F, Gonçalves J: Recombinant single-chain variable fragment and single domain antibody piezoimmunosensors for detection of HIV-1 virion infectivity factor. Biosens Bioelectron 2007, 23:384-392.

82. Ibañez LI, De Filette $M$, Hultberg A, Verrips $T$, Temperton $N$, Weiss RA Vandevelde W, Schepens B, Vanlandschoot P, Saelens X: Nanobodies with in vitro neutralizing activity protect mice against $\mathrm{H} 5 \mathrm{~N} 1$ influenza virus infection. J Infect Dis 2011, 203:1063-1072.

83. Hultberg A, Temperton N, Rosseels V, Koenders M, Gonzalez-Pajuelo M, Schepens B, Ibañez LI, Vanlandschoot P, Schillemans J, Saunders M, Weiss RA, Saelens X, Melero JA, Verrips CT, Van Gucht S, de Haard HJ: Llama-derived single-domain antibodies to build multivalent, superpotent and broadened neutralizing anti-viral molecules. PLOS One 2011, 6:e17665.

84. Olichon A, Schweizer D, Muyldermans S, de Marco A: Heating represents a rapid purification method for recovering correctly folded thermo tolerant $\mathrm{VH}$ and $\mathrm{VHH}$ domains. BMC Biotechnol 2007, 7:7.

85. Dong J, Thompson AA, Fan Y, Lou J, Conrad F, Ho M, Pires-Alves M, Wilson BA, Stevens RC, Marks JD: A single-domain llama antibody potently inhibits the enzymatic activity of botulinum neurotoxin by binding to the non-catalytic a-exosite binding region. J Mol Biol 2010 397:1106-1118.

86. Doňa V, Urrutia M, Bayardo M, Alzogaray V, Goldbaum FA, Chirdo FG: Single domain antibodies are specially suited for quantitative determination of gliadins under denaturing conditions. J Agric Food Chem 2010, 58:918-926.

87. Liu JL, Anderson GP, Goldman ER: Isolation of anti-toxin single domain antibodies from a semi-synthetic spiny dogfish shark display library. BMC Biotechnol 2007, 7:78.

88. Liu JL, Anderson GP, Delehanty JB, Baumann R, Hayhurst A, Goldman ER: Selection of cholera toxin specific IgNAR single-domain antibodies from a naïve shark library. Mol Immunol 2007, 44:177-1783.

89. Goldman ER, Anderson GP, Bernstein RD, Swain MD: Amplification of immunoassays using phage-displayed single domain antibodies. J Immunol Meth 2010, 352:182-185.

90. Kim JS, Anderson GP, Erickson JS, Golden JP, Nasir M, Ligler FS: Multiplexed detection of bacteria and toxins using a microflow cytometer. Anal Chem 2009, 81:5426-5432.

91. Loyprasert S, Hedström M, Thavarungkul P, Kanatharana P, Mattiasson B: Sub-attomolar detection of cholera toxin using a label-free capacitive immunosensor. Biosens Bioelectron 2010, 25:1977-1983.

92. Slocik JM, Kim SN, Auvil T, Goldman ER, Liu J, Naik RR: Single domain antibody templated nanoparticle resistors for sensing. Biosens Bioelectron 2010, 25:1908-1913.

93. Alzogaray V, Danquah W, Aguirre A, Urrutia M, Berguer P, Garcia Vescovi E, Haag F, Koch-Nolte F, Goldbaum FA: Single-domain llama antibodies as specific intracellular inhibitors of SpvB, the actin ADP-ribosylating toxin of Salmonella typhimurium. FASEB J 2011, 25:526-234.

94. Hmila I, Ben-Abderrazek Ben-Abdallah R, Saerens D, Benlasfar Z, Conrath K, Ayeb ME, Muyldermans S, Bouhaouala-Zahar B: VHH, bivalent domains and chimeric Heavy chain-only antibodies with high neutralizing efficacy for scorpion toxin Aahl'. Mol Immunol 2008, 45:3847-3856.

95. Ben-Abderrazek Ben-Abdallah R, Hmila I, Vincke C, Benlasfar Z, Pellis M, Dabbek H, Saerens D, El Ayeb M, Muyldermans S, Bouhaouala-Zahar B: Identification of potent nanobodies to neutralize the most poisonous polypeptide from scorpion venom. Biochem J 2009, 424:263-272.

96. Hmila I, Saerens D, Ben-Abderrazek Ben-Abdallah R, Vincke C, Abidi N, Benlasfar Z, Govaert J, El Ayeb M, Bouhaouala-Zahar B, Muyldermans S: A bispecific nanobody to provide full protection against lethal scorpion envenoming. FASEB J 2010, 24:3479-3489.

97. Conrath EK, Lauwereys M, Wyns L, Muyldermans S: Camel single-domain antibodies as modular building units in bispecific and bivalent antibody constructs. J Biol Chem 2001, 276:7346-7350.

98. Zhang J, Tanha J, Hirama T, Khieu NH, To R, Tong-Sevinc H, Stone E, Brisson JR, MacKenzie CR: Pentamerization of single-domain antibodies from phage libraries: a novel strategy for the rapid generation of highavidity antibody. J Mol Biol 2004, 335:49-56. 
99. Stone E, Hirama T, Tanha J, Tong-Sevinc H, Li S, MacKenzie CR, Zhang J: The assembly of single domain antibodies into bispecific decavalent molecules. J Immunol Meth 2007, 318:88-94.

100. Stone E, Hirama T, Chen W, Soltyk AL, Brunton J, Mackenzie CR, Zhang J: A novel pentamer versus pentamer approach to generating neutralizers of verotoxin 1. Mol Immunol 2007, 44:2487-2491.

101. Stewart CS, MacKenzie CR, Hall JC: Isolation, characterization and pentamerization of alpha-cobrotoxin specific single-domain antibodies from a naïve phage display library: preliminary findings for antivenom development. Toxicon 49:699-709.

102. Hussack G, Arbabi-Ghahroudi M, van Faassen H, Songer JG, Ng KK, Mackenzie R, Tanha J: Neutralization of Clostridium difficile toxin A with single-domain antibodies targeting the cell-receptor binding domain. $J$ Biol Chem 2011, 286:8961-8976.

103. Adams H, Brummelhuis W, Maassen B, van Egmond N, El Khattabi M, Detmers F: Specific immuno capturing of the staphylococcal superantigen toxic-shock syndrome toxin-1 in plasma. Biotechnol Bioeng 2009, 104:143-151.

104. Brummelhuis W, Joles JA, Stam JC, Adams H, Goldschmeding R, Detmers FJ, El Khattabi M, Maassen BT, Verrips $C T$, Braam B: Llama heavy-chain antibody fragments efficiently remove toxic shock syndrome toxin 1 from plasma in vitro but not in experimental porcine septic shock. Shock 2010, 34:125-132.

105. Kabir ME, Krishnaswamy S, Miyamoto M, Furuichi Y, Komiyama T: An altered camelid-like single domain anti-idiotypc antibody fragment of HM-1 killer toxin: acts as an effective antifungal agent. Appl Microbiol Biotechnol 2011, 90:553-564.

106. Anderson GP, Matney R, Liu JL, Hayhurst A, Goldman ER: Multiplexed fluid array screening of phage displayed anti-ricin single domain antibodies for rapid assessment of specificity. Biotechniques 2007, 43:806-811.

107. Anderson GP, Liu JL, Hale ML, Bernstein RD, Moore M, Swain MD, Goldman ER: Development of antiricin single domain antibodies toward detection and therapeutic reagents. Anal Chem 2008, 80:9604-9611.

108. Anderson GP, Bernstein RD, Swain MD, Zabetakis D, Goldman ER: Binding kinetics of antiricin single domain antibodies and improved detection using a B chain specific binder. Anal Chem 2010, 82:7202-7207.

109. Goldman ER, Anderson GP, Conway J, Sherwood LJ, Fech M, Vo BH, Liu JL, Hayhurst A: Thermostable llama single domain antibodies for detection of botulinum A neurotoxin complex. Anal Chem 2008, 80:8583-8591.

110. Conway JO, Sherwood L, Collazo MT, Garza JA, Hayhurst A: Llama single domain antibodies specific for the 7 botulinum neurotoxin serotypes as heptaplex immunoreagents. PLoSOne 2010, 5:e8818.

111. Swain MD, Anderson GP, Zabetakis D, Bernstein RD, Liu JL, Sherwood L, Hayhurst A, Goldman ER: Llama-derived single-domain antibodies for the detection of botulinum A neurotoxin. Anal Bioanal Chem 2010, 398:339-348

112. Tremblay JM, Kuo C-L, Abeijon C, Sepulveda J, Oyler G, Hu X, Jin MM, Shoemaker CB: Camelid single domain antibodies (VHHs) as neuronal cell intrabody binding agents and inhibitors of Clostridium botulinum neurotoxin (BoNT) proteases. Toxicon 2010, 56:990-998.

113. Yau KYF, Groves MAT, Li S, Sheedy C, Lee H, Tanha J, MacKenzie CR, Jermutus L, Hall JC: Selection of hapten-specific single-domain antibodies from a non-immunized llama ribosome display library. J Immunol Meth 2003, 281:161-175.

114. Sheedy C, Yau KY, Hirama T, MacKenzie CR, Hall JC: Selection, characterization, and CDR shuffling of naïve llama single-domain antibodies selected against auxin and their cross reactivity with auxinic herbicides from four chemical families. J Agric Food Chem 2006, 54:3668-3678

115. Ladenson RC, Crimmins DL, Landt Y, Ladenson JH: Isolation and characterization of a thermally stable recombinant anti-caffeine heavychain antibody fragment. Anal Chem 2006, 78:4501-4508.

116. Alvarez-Rueda N, Behar G, Ferré V, Pugniere M, Roquet F, Gastinel L, Jacquot C, Aubry J, Baty D, Barbet J, Birklé S: Generation of Ilama singledomain antibodies against methotrexate, a prototypcal hapten. $\mathrm{Mol}$ Immunol 2007, 44:1680-1690.

117. Doyle PJ, Arbabi-Ghahroudi M, Gaudette N, Furzer G, Savard ME, Gleddie S: Cloning, expression, and characterization of a single-domain antibody fragment with affinity for 15-acetyl-deoxynivalenol. Mol Immunol 2008, 45:3703-3713.
118. Anderson GP, Goldman ER: TNT detection using llama antibodies and a two-step competitive fluid array immunoassay. J Immunol Meth 2008, 339:47-54.

119. Doyle PJ, Saeed H, Hermans A, Gleddie SC, Hussack G, Arbabi-Ghahroudi M, Seguin C, Savard ME, Mackenzie CR, Hall JC: Intracellular expression of a single domain antibody reduces cytotoxicity of 15-acetyldeoxynivalenol in yeast. J Biol Chem 2009, 284:35029-35039.

120. Kobayashi N, Oyama H, Nakao M, Kanda T, Banzono E, Kato Y, Karibe T, Nishio T, Goto J: "Cleavable" hapten-biotin conjugates: Preparation and use for the generation of anti-steroid single-domain antibody fragments. Anal Biochem 2009, 387:257-266.

121. Koide A, Tereshko V, Uysal S, Margalef K, Kossiakoff AA, Koide S: Exploring the capacity of minimalist protein interfaces: interface energetics and affinity maturation to picomolar KD of a single-domain antibody with a flat paratope. J Mol Biol 2007, 373:941-953.

122. Spinelli S, Frenken LGJ, Hermans P, Verrips T, Brown K, Tegoni M, Cambillau C: Camelid heavy-chain variable domains provide efficient combining sites to haptens. Biochemistry 2000, 39:1217-1222.

123. Spinelli S, Tegoni M, Frenken L, van Vliet C, Cambillau C: Lateral recognition of a dye hapten by a llama VHH domain. J Mol Biol 2001, 311:123-129.

124. Sonneson GJ, Horn JR: Hapten-induced dimerization of a single domain VHH camelid antibody. Biochemistry 2009, 48:6693-6695.

125. Verheesen $P$, ten Haaft MR, Lindner N, Verrips $C T$, de Haard JJW: Beneficial properties of single-domain antibody fragments for application in immunoaffinity purification and immuno-perfusion chromatography. Biochim Biophys Acta 2003, 1624:21-28.

126. McCue JT, Selvitelli K, Walker J: Application of a novel affinity adsorbent for the capture and purification of Factor VIII compound. J Chromatog A 2009, 1261:7824-7830.

127. Detmers F, Hermans P. Jiao J-A, McCue JT: Novel affinity ligands provide for highly selective primary capture. BioProcess Internatl 2010, 8:50-54.

128. Aliprandi M, Sparacio E, Pivetta F, Ossolengo G, Maestro R, de Marco A: The availability of a recombinant anti-SNAP antibody in $\mathrm{VHH}$ format amplifies the application flexibility of SNAP-tagged proteins. J Biomed Biotechnol 2010, ID 658954.

129. Franco EJ, Sonneson GJ, DeLegge TJ, Hofstetter H, Horn JR, Hofstetter O: Production and characterization of a genetically engineered anticaffeine camelid antibody and its use in immunoaffinity chromatography. J Chromatogr B 2010, 878:177-186.

130. Beyer T: Serum-free production and purification of chimeric IgA antibodies. J Immunol Meth 2009, 346:26-27.

131. Kuroiwa $Y$, Kasinathan $P$, Sathiyaseelan $T$, Jiao JA, Matsushita $H$, Sathiyaseelan J, Wu H, Mellquist J, Hammitt M, Koster J, Kamoda S, Tachibana K, Ishida I, Robl JM: Antigen-specific human polyclonal antibodies from hyperimmunized cattle. Nature Biotechnol 2009, 27:173-181.

132. Klooster R, Maassen BTH, Stam JC, Hermans PW, ten Haaft MR, Detmers FJM, de Haard HJ, Post JA, Verrips TC: Improved anti-lgG and HAS affinity ligands: Clinical application of $\mathrm{VHH}$ antibodies technology. $J$ Immunol Meth 2007, 324:1-12.

133. Rothbauer U, Zolghadr K, Muyldermans S, Schepers A, Cardoso MC, Leonhardt $\mathrm{H}$ : A versatile nanotrap for biochemical and functional studies with fluorescent fusion proteins. Mol Cel Proteomics 2008, 7:282-289.

134. Kubala MH, Kovtun O, Alexandrov K, Collins BM: Structural and thermodynamic analysis of the GFP:GFP-nanobody complex. Protein Sci 2010, 19:238-2401.

135. Low D, O'Leary R, Pujar NS: Future of antibody purification. J Chromatog $B$ 2007, 848:48-63.

136. Hellström M, Ruitenberg MJ, Pollett MA, Ehlert EM, Twisk J, Verhaagen J, Harvey AR: Cellular tropism and transduction properties of seven adenoassociated viral vector serotypes in adult retina after intravitreal injection. Gene Ther 2008, 16:521-532.

137. Smith RH, Levy JR, Kotin RM: A simplified baculovirus-AAV expression vector system coupled with one-step affinity purification yields hightiter rAAV stocks from insect cells. Mol Ther 2009, 17:1888-1896.

138. Capture Select. [http://www.captureselect.com].

139. Allele Biotechnology. [http://www.allelebiotech.com].

140. Bossi S, Ferranti B, Martinelli C, Capasso P, de Marco A: Antibody-mediated purification of co-expressed antigen-antibody complexes. Prot Expr Purif 2010, 72:55-58 
141. Saerens D, Huang L, Bonroy K, Muyldermans S: Antibody fragments as probe in biosensor development. Sensors 2008, 8:4669-4686.

142. Reulen SWA, van Baal I, Raats JMH, Merckx M: Efficient, chemioselective synthesis of immunomicelles using single-domain antibodies with Cterminal thioester. BMC Biotechnol 2009, 9:66

143. Oliveira S, Schiffelers RM, van der Veeken J, van der Meel R, Vongpromek R, van Bergen en Henegouwen PM, Storm G, Roovers RC: Downregulation of EGFR by a novel multivalent nanobody-liposome platform. J Control Release 2010, 145:165-175.

144. Even-Desrumeaux K, Baty D, Chames P: Strong and oriented immobilization of single domain antibodies from crude bacterial lysates for high-throughput compatible cost-effective antibody array generation. Mol BioSyst 2010, 6:2241-2248.

145. Huang L, Reekmans G, Saerens D, Friedt JM, Frederix F, Francis L, Muyldermans S, Campitelli A, Van Hoof C: Prostate-specific antigen immunosensing based on mixed self-assembled monolayers, camel antibodies and colloidal gold enhanced sandwich assays. Biosens Bioelectron 2005, 21:483-490.

146. Saerens D, Frederix F, Reekmans G, Conrath K, Jans K, Brys L, Huang L, Bosmans E, Maes G, Borghs G, Muyldermans S: Engineering camel singledomain antibodies and immobilization chemistry for human prostatespecific antigen sensing. Anal Chem 2005, 77:7547-7555.

147. Huang L, Gainkam LO, Caveliers V, Vanhove C, Keyaerts M, De Baetseliers P, Bossuyt A, Revets $H$, Lahoutte T: SPECT imaging with $99 m$ mc-labeled EGFR-specific nanobody for in vivo monitoring of EGFR expression. Mol Imaging Biol 2008, 10:165-175.

148. Gainkam LO, Huang L, Caveliers V, Keyaerts M, Hernot S, Vaneycken I, Vanhove C, Revets H, De Baetselier P, Lahoutte T: Comparison of the biodistribution and tumor targeting of two $99 \mathrm{mTc}$-labeled anti-EGFR nanobodies in mice, using pinhole SPECT/micro-CT. J Nucl Med 2008, 49:788-795.

149. De Groeve K, Deschacht N, De Koninck C, Caveliers V, Lahoutte T, Devoogdt N, Muyldermans S, De Baetselier P, Raes G: Nanobodies as tools for in vivo imaging of specific immune cell types. J NuCl Med 2010, 51:782-789.

150. Tchouate Gainkam LO, Keyaerts M, Caveliers V, Devoogdt N, Vanhove C, Van Grunsven L, Muyldermans S, Lahoutte T: Correlation between epidermal growth factor receptor-specific nanobody uptake and tumor burden: A tool for noninvasive monitoring of tumor response to therapy. Mol Imaging Biol 2010, PMID: 20865332.

151. Tchouate Gainkam LO, Caveliers V, Devoogdt N, Vanhove C, Xavier C, Boerman O, Muyldermans S, Bossuyt A, Lahoutte T: Localization, mechanism and reduction of renal retention of technetium-99m labeled epidermal growth factor receptor-specific nanobody in mice. Contrast Media Mol Imaging 2010, 6:85-92.

152. Vaneycken I, Devoogdt N, Van Gassen N, Vincke C, Xavier C, Wernery U, Muyldermans S, Lahoutte T, Caveliers V: Preclinical screening of anti-HER2 nanobodies for molecular imaging of breast cancer. FASEB J 2011, PMID: 21478264.

153. Vosjan MJ, Perk LR, Roovers RC, Visser GW, Stigter-van Walsum M, van Bergen En Henegouwen PM, van Dongen GA: Facile labeling of an antiepidermal growth factor receptor nanobody with (68)Ga via a novel bifunctional desferal chelate for immuno-PET. Eur J Nucl Med Mol Imaging 2011, 38:753-763.

154. Yokota T, Milenic DE, Whitiow M, Schlom J: Rapid tumor penetration of a single-chain Fv and comparison with other immunoglobulin forms. Cancer Res 1992, 52:3402-3408.

155. Tijink BM, Laeremans T, Budde M, Stigter-van Walsum M, Dreier T, de Haard HJ, Leemans CR, van Dongen GA: Improved tumor targeting of anti-epidermal growth factor receptor Nanobodies through albumin binding: taking advantage of modular nanobody technology. Mol Cancer Ther 2008, 7:2288-2297.

156. Iqbal U, Albaghdadi H, Nieh MP, Tuor UI, Mester Z, Stanimirovic D, Katsaras J, Abulrob A: Small unilamellar vesicles: a platform technology for molecular imaging of brain tumors. Nanotechnology 2011, 22:195102.

157. Amit AG, Mariuzza RA, Phillips SE, Poljak RJ: Three-dimensional structure of an antigen-antibody complex at $2.8 \AA$ resolution. Science 1986 , 233:747-753.

158. Hunte $\mathrm{C}$, Michel $\mathrm{H}$ : Crystallization of membrane proteins mediated by antibody fragments. Curr Opin Struct Biol 2002, 12:503-508.
159. Ermolenko DN, Zherdev AV, Dzantiev BB: Antibodies as specific chaperones. Biochemistry (Moscow) 2004, 69:1233-1238.

160. Hogbom M, Eklund M, Nygren PA, Nordlund P: Structural basis for recognition by an in vitro evolved affibody. Proc Natl Acad Sci USA 2003, 100:3191-3196.

161. Lipovšek D, Lippow SM, Hackel BJ, Gregson MW, Cheng P, Kapila A, Wittrup KD: Evolution of an interloop disulfide bond in high-affinity antibody mimics based on fibronectin type III doman and selected by yeast surface display: molecular convergence with single-domain camelid and shark antibodies. J Mol Biol 2007, 368:1024-1041.

162. Sennhauser G, Grütter MG: Chaperone-assisted crystallography with DARPins. Structure 2008, 16:1443-1453.

163. Tereshko V, Uysal S, Koide A, Margalef K, Koide S, Kossiakoff AA: Toward chaperone-assisted crystallography: Protein engineering enhancement of crystal packing and X-ray phasing capabilities of a camelid singledomain antibody (VHH) scaffold. Prot Sci 2008, 17:1175-1187.

164. Dolk E, van Vliet C, Perez JM, Vriend G, Darbon H, Ferrat G, Cambillau C, Frenken $L G$, Verrips $T$ : Induced refolding of a temperature denatured llama heavy-chain antibody fragment by its antigen. Proteins 2005 , 59:555-564.

165. Stanfield RL, Dooley H, Verdino P, Flajnik MF, Wilson IA: Maturation of shark single-domain (IgNAR) antibodies: evidence for induced-fit binding. J Mol Biol 2007, 367:358-372.

166. Loris R, Marianovsky I, Lah J, Laeremans T, Engelberg-Kulka H, Glaser G, Muyldermans S, Wyns L: Crystal structure of the intrinsically flexible addition antidote MazE. J Biol Chem 2003, 278:28252-28257.

167. Conrath K, Pereira AS, Martins CE, Timoteo CG, Tavares P, Spinelli S, Kinne J, Flaudrops C, Cambillau C, Muyldermans S, Moura I, Moura JJ, Tegoni M, Desmyter A: Camelid nanobodies raised against an integral membrane enzyme, nitric oxide reductase. Prot Sci 2009, 18:619-628.

168. Korotkov KV, Pardon E, Steyaert J, Hol WG: Crystal structure of the Nterminal domain of the secretin GspD from ETEC determined with the assistance of a nanobody. Structure 2009, 17:255-265.

169. Lam AY, Pardon E, Korotkov KV, Hol WG, Steyaert J: Nanobody-aided structure determination of the Epsl:EpsJ pseudopilin heterodimer from Vibrio vulnificus. J Struct Biol 2009, 166:8-15.

170. Wu M, Park Y-J, Pardon E, Turley S, Hayhurst A, Deng J, Steyaert J, Hol WG Structures of a key interaction protein from the Trypanosoma brucei editosome in complex with single domain antibodies. J Struct Bio/ 2010, 174:124-136.

171. Rasmussen SGF, Choi H-J, Fung JJ, Pardon E, Casarosa P, Chae PS, Devree BT, Rosenbaum DM, Thian FS, Kobilka TS, Schnapp A, Konetzki I, Sunahara RK, Gellman SH, Pautsch A, Steyaert J, Weis WI, Kobilka BK: Structure of a nanobody-stabilized active state of the $\beta 2$ adrenoceptor. Nature 2011, 469:175-180.

172. Koide S: Engineering of recombinant crystallization chaperones. Curr Opin Struct Biol 2009, 19:449-457.

173. Abskharon RN, Soror SH, Pardon E, El Hassan H, Legname G, Steyaert J, Wohlkonig A: Crystallization and preliminary X-ray diffraction analysis of a specific VHH domain against mouse prion protein. Acta Crystallogr Sect F Struct Biol Cryst Commun 2010, 66:1644-1646.

174. Dumoulin M, Last AM, Desmyter A, Decanniere K, Canet D, Larsson G, Spencer A, Archer DB, Sasse J, Muyldermans S, Wyns L, Redfield C, Matagne A, Robinson CV, Dobson CM: A camelid antibody fragment inhibits the formation of amyloid fibrils by human lysozyme. Nature 2003, 424:783-788.

175. Habicht G, Haupt C, Friedrich RP, Hortschansky P, Sachse C, Meinhardt J, Wieligmann K, Gellermann GP, Brodhun M, Götz J, Halbhuber KJ, Röcken C, Horn U, Fändrich M: Directed selection of a conformational antibody domain that prevents mature amyloid fibril formation by stabilizing Abeta protofibrils. Proc Natl Acad Sci USA 2007, 104:19232-19237.

176. Lafaye P, Achour I, England P, Duyckaerts C, Rougeon F: Single-domain antibodies recognize selectively small oligomeric forms of amyloid beta, prevent Abeta-induced neurotoxicity and inhibit fibril formation. $\mathrm{Mol}$ Immunol 2009, 46:695-704.

177. Kasturirangan S, Li L, Emadi S, Boddapati S, Schulz P, Sierks MR: Nanobody specific for oligomeric beta-amyloyd stabilizes nontoxic form. Neurobiol Aging 2010, PMID: 21067847.

178. Kasturirangan S, Boddapati S, Sierks MR: Engineered proteolytic nanobodies reduce Abeta burden and ameliorate Abeta-induced cytotxicity. Biochemistry 2010, 49:4501-4508. 
179. Domanska K, Vanderhaegen S, Srinivasan V, Pardon E, Dupeux F, Marquez JA, Giorgetti S, Stoppini M, Wyns L, Bellotti V, Steyaert J: Atomic structure of a nanobody-trapped domain-swapped dimmer of an amyloidogenic \{beta\}2-microglobulin variant. Proc Natl Acad Sci USA 2011, 108:1314-1319.

180. Streltsov VA, Varghese JN, Masters CL, Nuttal SD: Crystal structure of the amylod-\{beta\} p3 fragment provides a model for oligomeric formation in Alzheimer's disease. J Neurosci 2011, 31:1419-1426.

181. Oyen D, Srinivasan V, Steyaert J, Barlow JN: Constraining enzyme conformational change by an antibody leads to hyperbolic inhibition. $J$ Mol Biol 2011, 407:138-148.

182. Barlow JN, Conrath K, Steyaert J: Substrate-dependent modulation of enzyme activity by allosteric effector antibodies. Biochim Biophys Acta 2009, 1794:1259-1268

183. Paalanen MM, Ekokoski E, El Khattabi M, Tuominen RK, Verrips CT, Boonstra J, Blanchetot C: The development of activating and inhibiting camelid VHH domains against human protein kinase $\mathrm{C}$ epsilon. Eur J Pharm Sci 2011, 42.332-339.

184. De Genst E, Silence K, Decanniere K, Conrath K, Loris R, Kinne J, Muyldermans S, Wyns L: Molecular basis for the preferential cleft recognition by dromedary heavy-chain antibodies. Proc Natl Acad Sci USA 2006, 103:4586-4591.

185. Verheesen P, Roussis A, de Haard HJ, Groot EH, Stam JC, den Dunnen JT, Frants RR, Verkleij AJ, Theo Verrips C, van der Maarel SM: Reliable and controllable antibody fragment selections from camelid non-immune libraries for target validation. Biochim Biophys Acta 2006, 1764:1307-1319.

186. Simmons DP, Streltsov VA, Dolezal O, Hudson PJ, Coley AM, Foley M, Proll DF, Nuttall SD: Shark IgNAR antibody mimotopes target a murine immunoglobulin through extended CDR3 loop structure. Proteins 2008, 71:119-130.

187. Veggiani G, Ossolengo G, Aliprandi M, Cavallaro U, de Marco A: Singledomain antibodies that compete with the natural ligand Fibroblast Growth Factor block the internalization of the Fibroblast Growth Factor Receptor1. Biochem Biophys Res Comm 2011, 408:692-696.

188. Daugherty PS, Olsen MJ, Iverson BL, Georgiou G: Development of an optimized expression system for the screening of antibody libraries displayed on the Escherichia coli surface. Prot Engineer 1999, 12:613-621.

189. Feldhaus MJ, Siegel RW, Opresko LK, Coleman JR, Weaver Feldhaus JM, Yeung YA: Flow-cytometry isolation of human antibodies from a nonimmune Saccharomices cerevisiae surface display library. Nat Biotechnol 2003, 21:163-170.

190. Mattanovich D, Borth N: Applications of cell sorting in biotechnology. Microb Cell Fact 2006, 5:12.

191. Zahnd C, Amstutz P, Plückthun A: Ribosome display: selecting and evolving proteins in vitro that specifically bind to a target. Nat Methods 2007, 4:269-279.

192. Mao H, Graziano JJ, Chase TMA, Bentley CA, Bazirgan OA, Reddy NP Song BD, Smider W: Spatially addressed combinatorial protein libraries for recombinant antibody discovery and optimization. Nat Biotechnol 2010, 28:1195-2202.

193. Thurber GM, Schmidt MM, Wittrup KD: Antibody tumor penetration: transport opposed by systemic and antigen-mediated clearance. Adv Drug Deliv Rev 2008, 60:1421-1434.

194. Rudnick SI, Adams GP: Affinity and avidity in antibody-based tumor targeting. Cancer Biother Radiopharm 2009, 24:155-160.

195. Paal M, Heel T, Schneider R, Auer B: A novel Ecotin-Ubiquitin-Tag (ECUT) for efficient, soluble peptide production in the periplasm of Escherichia coli. Microb Cell Fact 2009, 8:7.

196. de Marco A: Strategies for successful recombinant expression of disulfide bond-dependent proteins in Escherichia coli. Microb Cell Fact 2009, 8:26.

197. Joosten V, Lokman C, van den Hondel CAMJJ, Punt PJ: The production of antibody fragments and antibody fusion proteins by yeast and filamentous fungi. Microb Cell Fact 2003, 2:1.

198. Hatahet F, Nguyen VD, Salo KEH, Ruddock LW: Disruption of reducing pathways is not essential for efficient disulfide bond formation in the cytoplasm of E. coli. Microb Cell Fact 2010, 9:67.

199. Nguyen VD, Hatahet F, Salo KEH, Enlund E, Zhang C, Ruddock LW: Preexpression of a sulfhydryl oxidase significantly increases the yields of eukaryotic disulfide bond containing proteins expressed in the cytoplasm of E. coli. Microb Cell Fact 2011, 10:1.
200. Veggiani G, de Marco A: Improved quantitative and qualitative production of single-domain intrabodies mediated by the co-expression of Erv1p sulfhydryl oxidase. Prot Expr Purif 2011, PMID: 201. 21421053.

201. Bradbury ARM, Sidhu S, Dübel S, McCafferty J: Beyond natural antibodies: the power of in vitro display technologies. Nat Biotechnol 2011, 29:245-254.

\section{doi:10.1186/1475-2859-10-44}

Cite this article as: de Marco: Biotechnological applications of recombinant single-domain antibody fragments. Microbial Cell Factories 2011 10:44

\section{Submit your next manuscript to BioMed Central and take full advantage of:}

- Convenient online submission

- Thorough peer review

- No space constraints or color figure charges

- Immediate publication on acceptance

- Inclusion in PubMed, CAS, Scopus and Google Scholar

- Research which is freely available for redistribution

Submit your manuscript at www.biomedcentral.com/submit
C Biomed Central 